\title{
4
}

\section{Validation of Primary Packaging for Cryopreserved Musculoskeletal Tissues}

\author{
Luiz Augusto Ubirajara Santos ${ }^{1}$, Rosa Maria Vercelino Alves², Alberto T. \\ Croci1', Fábio Gomes Teixeira², Paulo Henrique Kiyataka², Marisa Padula², \\ Mary Ângela Fávaro Perez², Monica Beatriz Mathor', Renata Miranda \\ Parca6, Arlete M.M . Giovani', Cesar Augusto Martins Pereira4, Graziela \\ Guidoni Maragni ${ }^{1}$, Thais Queiróz Santolin ${ }^{1}$ and Lucas da Silva Pereira ${ }^{5}$
}

\section{Introduction}

Bones and tendons are obtained from donors who have been pronounced brain dead after a rigid and extensive screening process. The tissues obtained are sent to a Tissue Bank and submitted to processing steps, packaging and cryopreservation at $-80{ }^{\circ} \mathrm{C}$. It is vital to maintain sterility and integrity, so that no tissue is discarded.These precautions also extend to the packaging, which should promote containment and protection. Although minimum technical criteria have already been defined for the food industry, this has still not been regularized in Brazil. We emphasize, therefore, the need to study this subject, focusing on maintaining the quality of the musculoskeletal tissues produced by tissue banks. All procedures developed byTissue Banks currently present in the country have rigid control over the quality and the traceability of tissues made available, based on international standards (EATB, 2004; AATB, 2007) on the legislation (BRASIL, 1997-2006) and in conformity with Good Manufacturing Practices - GMP.

\section{Cryopreservation of musculoskeletal tissues}

In the cryopreservation room, the tissues are stored according to their status in the process. Thus, there are designated areas for tissues under analysis or in quarantine (where they remain for around 60 days before the result of all the exams) and for those that have been liberated for use. both areas are equipped with ultra-low temperature freezers, with temperatures ranging from minus 80 to minus 100 degrees Celsius.

${ }^{1}$ Institute of Orthopedics and Traumatology, Hospital das Clinicas of the University of São Paulo School of Medicine, Sao Paulo, SP, Brazil

2Packaging Technology Center - Institute of Food Technology, Campinas, SP, Brazil

${ }^{3}$ Nuclear and Energy Research Institute - IPEN/CNEN-SP - São Paulo, Brazil

${ }^{4}$ Biomechanics Laboratory - Institute of Orthopedics and Traumatology, Hospital das Clinicas of the University of São Paulo school of Medicine, Brazil

${ }^{5}$ Dental Student Institute of Orthopedics and Traumatology, Hospital das Clínicas of the University of São Paulo school of Medicine, São Paulo, SP, Brazil

${ }^{6}$ National Health Surveillance Agency- ANVISA 
The room is also equipped with an air conditioning system, its own energy generator, and carbon gas backup as protection against defrosting, as well as a rigorous temperature monitoring system that generates 24-hour printed temperature recordings, and a satellite alarm system, which ensures adequate maintenance of the temperature and early detection of any flaws.

Depending on the results of the analyses, the tissues are transferred to the room designated for materials liberated for use. The maximum cryopreservation period is 5 years for bone tissue and 2 years for soft or tendinous tissues.

It is vital to maintain sterility and integrity, in order to avoid disposal of any material. This is the purpose of packaging, which is aimed at containment and protection. In Brazil, there are no specific regulations for packaging of sterile, cryopreserved tissues for transplants, and in this chapter, we present our experience in the definition and validation of a type of packaging used for this purpose. Our proposal is to characterize a coextruded plastic film structure used for packaging of musculoskeletal tissues at low temperatures, in regard to the aspects sterility, cytotoxicity, migration, mechanical resistance and oxygen permeability.

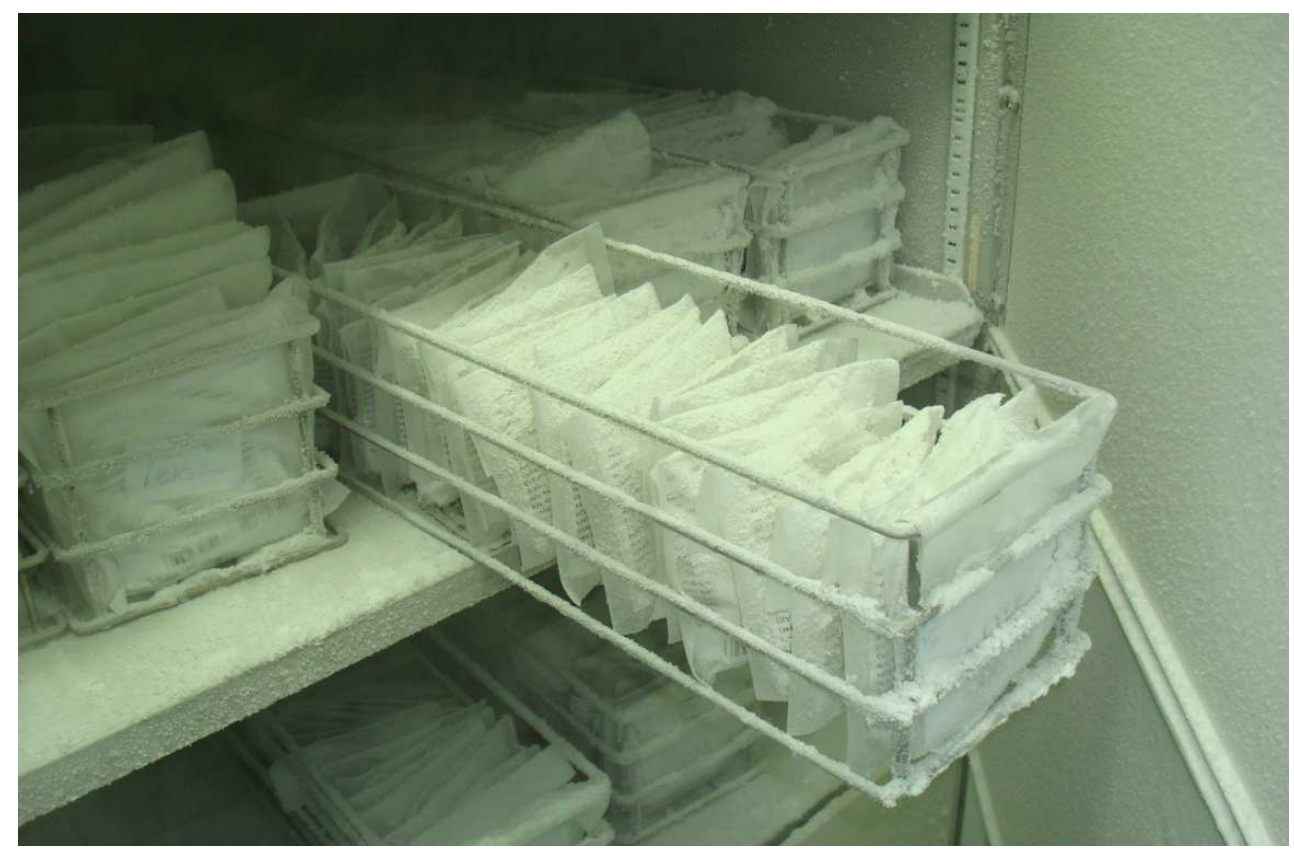

Fig. 1. Cryopreservation of tissues at $-80 \circ \mathrm{C}$ in drawers, separated by batches.

\section{Validation of packaging for use in tissue cryopreservation.}

\subsection{Description of our sample}

A roll of transparent, unprinted seven layers, coextruded plastic: 
Layer 01: LLDPE - 1-octene comonomer Linear Low-Density Polyethylene Layer 02: LLDPE - 1-octene comonomer Linear Low-Density Polyethylene and 1-octene comonomer Linear Low-Density Polyethylene modified with anhydride maleic Layer 03: PA - hexamethylenediamine, adipic acid e caprolactam copolyamide Layer 04: LLDPE - 1-octene comonomer Linear Low-Density Polyethylene and 1-octene comonomer Linear Low-Density Polyethylene modified with anhydride maleic Layer 05: PA - hexamethylenediamine, adipic acid e caprolactamcopolyamide Layer 06: LLDPE - 1-octene comonomer Linear Low-Density Polyethylene and 1-octene comonomer Linear Low-Density Polyethylene modified with anhydride maleic Layer 07: LLDPE - 1-octene comonomer Linear Low-Density Polyethylene

In relation to the physicomechanical and barrier properties characteristics, we investigated the alterations that occurred in the packages after 30, 60, 90, 120, and 150 days of cryopreservation at $-80{ }^{\circ} \mathrm{C}$. For the cytotoxicity and sterility analysis, two groups (before and after sterilization by ethylene oxide) were analysed.

\subsection{Physicomechanical and barrier properties tests}

\section{A) Characterization of coex film in relation to its thickness and water vapor transmission rate (WVTR)}

The thickness of each layer of plastic material in the film sample was determined through images captured by a Metaval inverted microscope operating at a magnification of 200x, using the image analysis system Axio Vision (Zeiss ${ }^{\circledR}$ ). The cross-section of the sample was obtained using a Leica microtome, model RM2245, with section thickness set to $40 \mu \mathrm{m}$. To facilitate visualization of the barrier layer, $2 \%$ iodine solution was used as a contrasting agent. Five cross-section samples of the material were obtained; five measurements were performed for each sample, totalling 25 thickness measurements. The test was carried out at a temperature of around $23^{\circ} \mathrm{C}$, after packaging of the sample in a controlled environment at $23^{\circ} \mathrm{C} \pm 2^{\circ} \mathrm{C}$ and $(50 \pm 3) \%$ relative humidity for a minimum period of 48 hours.

The water vapor transmission rate was determined using a MOCON PERMATRAN-W 3/31 device, following the procedure described in regulation ASTM F1249-06 - Standard test methods for water vapor transmission rate through plastic film and sheeting using a modulated infrared sensor. In this test, the water vapor that passes through the film is carried to the infrared sensor by ultra-dry nitrogen flow. The sensor measures the fraction of energy absorbed by the water vapor, and emits an electrical signal with amplitude proportional to the concentration of water vapor. The range of this signal is compared with that of the signal produced by the water vapor that passes through a calibration film with a known water vapour transmission rate. The effective permeation area of each sample was $50 \mathrm{~cm}^{2}$. The assay was performed at $38{ }^{\circ} \mathrm{C} / 100 \% \mathrm{RH}$ and in this condition, the calibration standard showed water vapour transmission rate of $4.54 \mathrm{~g}$ water. $\mathrm{m}^{-2}$.day ${ }^{-1}$. The water vapor transmission rate of the sample was corrected for the condition $38{ }^{\circ} \mathrm{C} / 90 \% \mathrm{RH}$, multiplying the results by a factor of 0.9 .

The total thickness of each layer of coextruded film is shown in Table 1. Figure 10 shows an example of a cross-section image of the sample obtained for the assay. 


\begin{tabular}{cccc}
\hline \multirow{2}{*}{ Determinations } & \multicolumn{3}{c}{ Thickness $(\mu \mathrm{m})$} \\
\cline { 2 - 4 } & Mean & Variation Interval & Coefficient of variation (\%) \\
\hline Total & 91.1 & $90.0-92.9$ & 0.9 \\
\hline LLDPE (A) & 27.3 & $26.2-28.5$ & 2.4 \\
\hline LLDPE blend (B) & 7.6 & $7.0-8.0$ & 3.8 \\
\hline PA (C) & 5.6 & $5.1-5.9$ & 4.8 \\
\hline LLDPE blend (D) & 6.8 & $5.3-7.8$ & 5.6 \\
\hline PA (C) & 5.6 & $5.0-6.0$ & 5.9 \\
\hline LLDPE blend (F) & 7.7 & $7.1-8.6$ & 1.9 \\
\hline LLDPE (G) & 31.0 & $30.1-32.1$ & \\
\hline
\end{tabular}

Values for 25 measurements

A-G: Text for visualization in Figure 10

Table 1. Total thickness of each layer of sample of coextruded plastic film.

Thus, by optical microscopy, it was observed that it is a coextruded material with seven layers, with two intermediate layers of PA of approximately $6 \mu \mathrm{m}$ each. The other LLDPE layers totalled $80 \mu \mathrm{m}$.

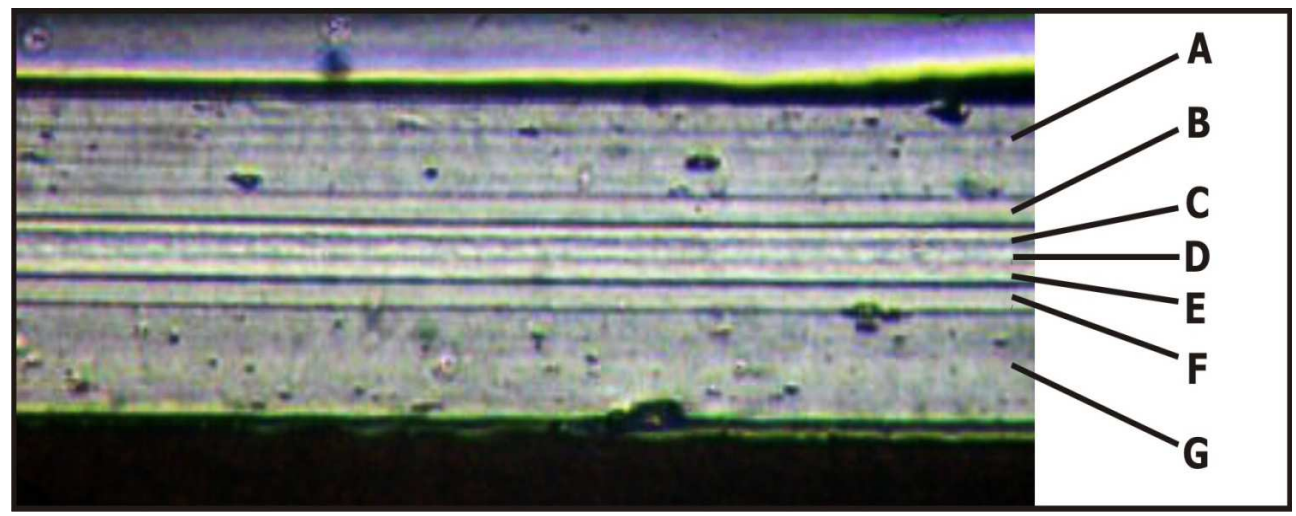

Fig. 2. Example of cross-section image of the sample obtained with the microscope operating at a magnification of 200x.

The characterization of the film in relation to water vapor transmission rate is shown in Table 2. 


\begin{tabular}{cccc}
\hline Sample & \multicolumn{3}{c}{ WVTR (g water . m-2.day-1) } \\
\cline { 2 - 4 } & Mean & VI & CV (\%) \\
\hline $\begin{array}{c}\text { Coextruded film } \\
\text { LLDPE / LLDPE / PA / LLDPE / PA / } \\
\text { LLDPE / LLDPE }\end{array}$ & 3.30 & $3.2-3.4$ & 4.4 \\
\hline
\end{tabular}

Values relate to four measurements

VI - variation interval; CV - coefficient of variation

Table 2. Water vapor transmission rate (WVTR) of the coextruded plastic film at $38^{\circ} \mathrm{C} / 90 \% \mathrm{RH}$ - Permatran-W 3/31 method.

The WVTR depends on the thickness of the LLDPE layers of the coex film $(80 \mu \mathrm{m})$.

\section{B) Penetration resistance}

The penetration resistance of the coextruded film was determined based on Standard ASTM F 1306-90 (2008) e1 - Standard test method for slow rate penetration resistance of flexible barrier films and laminates, on an Instron 5500R universal testing machine, using load cells of $100 \mathrm{~N}$. The speed of penetration, performed with a spherical-tipped metal probe with diameter of approximately $3.2 \mathrm{~mm}$, was $25 \mathrm{~mm} / \mathrm{min}$. The penetration was performed from the inner surface to the outer surface of the material. The test was conducted in an environment of $23^{\circ} \mathrm{C} \pm 2{ }^{\circ} \mathrm{C}$ and $(50 \pm 3) \%$ relative humidity, after leaving the packaged samples for a minimum period of 48 hours in this environment.

The evaluation of penetration resistance was carried out on samples in their original or nonfrozen condition (0) and 30, 60, 120 and 150 days after freezing at $-80 \circ \mathrm{C}$. The data are shown in Table 3 and Figure 3.

\begin{tabular}{|c|c|c|c|c|c|c|c|}
\hline \multirow{2}{*}{\multicolumn{2}{|c|}{$\begin{array}{l}\text { Penetration } \\
\text { resistance }\end{array}$}} & \multicolumn{6}{|c|}{ Evaluation periods (days) } \\
\hline & & 0 & 30 & 60 & 90 & 120 & 150 \\
\hline \multirow{3}{*}{$\begin{array}{c}\text { Force at break } \\
\text { (N) }\end{array}$} & Mean & $12.1 \mathrm{ab}$ & $12.6 \mathrm{bc}$ & $12.9 \mathrm{c}$ & $12.6 \mathrm{bc}$ & $11.1^{\mathrm{d}}$ & $11.8^{a}$ \\
\hline & VI & $11.5-12.7$ & $11.8-13.5$ & $11.9-14.2$ & $11.2-14.1$ & $9.4-12.3$ & $10.9-12.4$ \\
\hline & CV (\%) & 3.1 & 3.6 & 4.7 & 6.9 & 9.1 & 3.7 \\
\hline \multirow{3}{*}{$\begin{array}{l}\text { Deformation } \\
\text { at break }(\mathrm{mm})\end{array}$} & Mean & $9.4^{\mathrm{a}}$ & $11.0^{b}$ & $10.0^{c}$ & $9.8^{c}$ & $8.3^{\mathrm{d}}$ & 9.0 e \\
\hline & VI & $9.2-9.8$ & $10.7-11.4$ & $9.5-10.5$ & $8.9-10.6$ & $7.4-9.1$ & $8.2-9.5$ \\
\hline & CV (\%) & 2.3 & 2.3 & 2.6 & 5.2 & 5.5 & 3.7 \\
\hline \multirow{3}{*}{$\begin{array}{l}\text { Energy at } \\
\text { break (mJ) }\end{array}$} & Mean & 70 ad & $76^{b}$ & $78^{b}$ & $73 \mathrm{ab}$ & $62 \mathrm{c}$ & $69 \mathrm{~d}$ \\
\hline & VI & $64-74$ & $70-84$ & $72-85$ & $64-86$ & $52-73$ & $62-73$ \\
\hline & $\overline{C V}(\%)$ & 4.6 & 5.5 & 5.4 & 8.6 & 11 & 5.6 \\
\hline
\end{tabular}

Values relate to 10 measurements: $1 \mathrm{~N}=0.102 \mathrm{kgf}$

$\mathrm{VI} / \mathrm{CV}$ : Variation interval/Coefficient of variation

$\mathrm{a}, \mathrm{b}, \mathrm{c}, \mathrm{d}$ : for an analyzed property, mean values on the same line accompanied by the same superscript letter did not show any difference between them in the least significant difference (LSD) test, at a level of error of $5 \%$.

Table 3. Penetration resistance of the sample during storage at $-80^{\circ} \mathrm{C}$. 


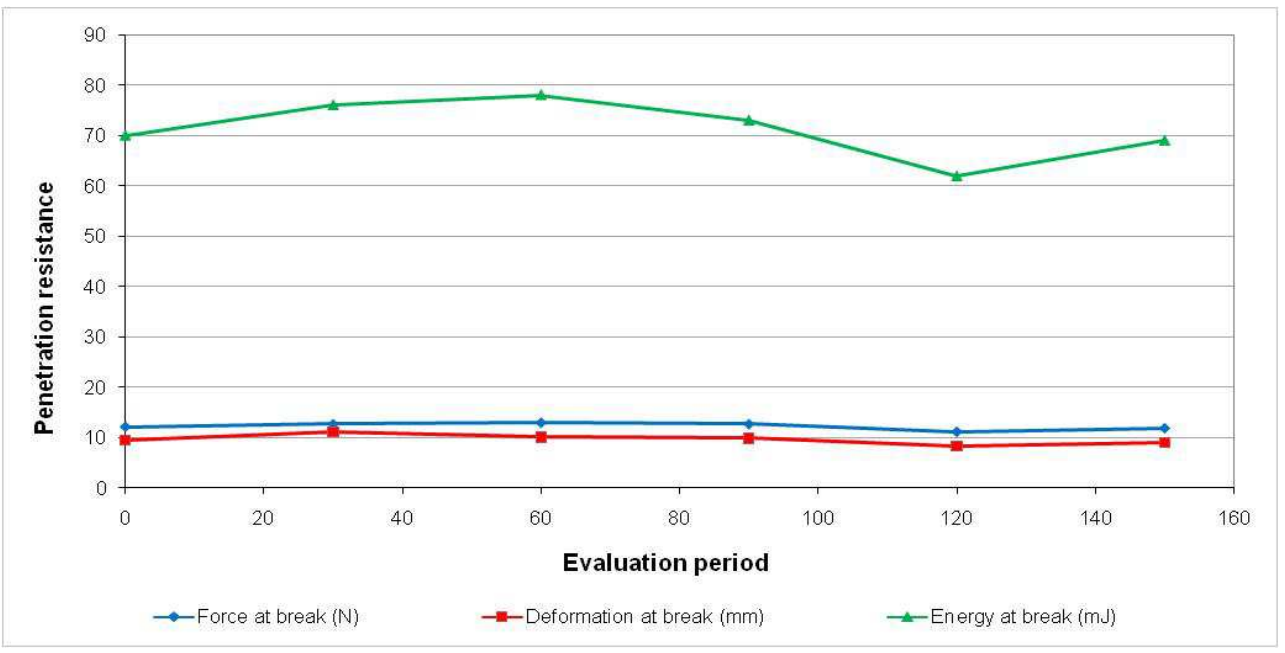

Fig. 3. Penetration resistance of the sample during the period of storage at $-80^{\circ} \mathrm{C}$ (days).

The results shown in Table 3 and Figure 3 demonstrate that the process of sterilization and packaging of human bone, and storage for 150 days at $-80^{\circ} \mathrm{C}$, did not alter the penetration properties of the coextruded film. Variations were observed in the results of the three properties evaluated, including statistical differences in some periods/properties, but as these variations were small, without any clearly-defined trend, no alteration is expected in penetration resistance of the film during packaging and storage of human tissue for a period of 150 days at $-80^{\circ} \mathrm{C}$.

\section{C) Seal strength}

The seal strength of the packaging was determined according to ASTM F 88/F 88M-09 Standard test method for seal strength of flexible barrier materials. Samples of $25.4 \mathrm{~mm}$ in width were submitted to tensile test in a 5500R Instron universal testing machine, operating with load cells of $50 \mathrm{~N}$ and $100 \mathrm{~N}$, at a speed of $300 \mathrm{~mm} / \mathrm{min}$. The distance between the fixing clamps and the sample was $25 \mathrm{~mm}$. The test was conducted in an environment of $23{ }^{\circ} \mathrm{C} \pm 2$ ${ }^{\circ} \mathrm{C}$ and $(50 \pm 3) \%$ relative humidity, after leaving the pre-prepared, packaged samples in this same environment for at least 48 hours.

The strength of the side seal is different from that of the top seal, because the top seal of the packaging was made after the bone tissue packaging process, while the side seals were made by the package manufacturer.

Despite this, there was no statistical difference between the results obtained for both seals. Thus, the sterilization and packaging process of human tissue, and storage for 150 days at $80^{\circ} \mathrm{C}$ did not alter the seal strength. 


\begin{tabular}{|c|c|c|c|c|c|c|c|}
\hline \multirow{2}{*}{\multicolumn{2}{|c|}{$\begin{array}{c}\text { Maximum seal strength } \\
(\mathrm{kgf} / 25.4 \mathrm{~mm})\end{array}$}} & \multicolumn{6}{|c|}{ Evaluation periods (days) } \\
\hline & & 0 & 30 & 60 & 90 & 120 & 150 \\
\hline \multirow{3}{*}{ Side seal } & Mean & $3.60 \mathrm{ab}$ & $3.65 \mathrm{~b}$ & $3.60 \mathrm{ab}$ & $3.73 \mathrm{~b}$ & $3.73 \mathrm{~b}$ & $3.44 \mathrm{a}$ \\
\hline & VI & $\begin{array}{c}3.36- \\
3.95 \\
\end{array}$ & $\begin{array}{c}3.41- \\
3.83 \\
\end{array}$ & $\begin{array}{c}3.38- \\
3.80 \\
\end{array}$ & $\begin{array}{c}3.34- \\
3.97 \\
\end{array}$ & $\begin{array}{c}3.43- \\
3.96 \\
\end{array}$ & $\begin{array}{c}3.12- \\
3.78 \\
\end{array}$ \\
\hline & CV (\%) & 4.4 & 4.0 & 4.4 & 5.7 & 4.5 & 7.0 \\
\hline \multirow{3}{*}{ Top seal } & Mean & - & 4.69 a & 4.75 a & $5.07 \mathrm{a}$ & 5.09 a & 4.84 a \\
\hline & VI & - & $\begin{array}{c}3.65- \\
5.20\end{array}$ & $\begin{array}{c}3.20- \\
5.85\end{array}$ & $\begin{array}{c}4.31- \\
5.95\end{array}$ & $\begin{array}{c}4.68- \\
5.54\end{array}$ & $\begin{array}{c}4.48- \\
5.44 \\
\end{array}$ \\
\hline & CV (\%) & - & 9.6 & 15 & 9.6 & 5.1 & 6.6 \\
\hline
\end{tabular}

Values relate to ten determinations: $1 \mathrm{kgf} / 25.4 \mathrm{~mm}=386.1 \mathrm{~N} / \mathrm{m}$

$\mathrm{VI} / \mathrm{CV}$ : Variation interval/Coefficient of variation

$\mathrm{a}, \mathrm{b}$ : for a seal type, mean values on the same line accompanied by the same superscript letter did not show any difference between them in the least significant difference (LSD) test, at a level of error of $5 \%$.

Table 4 . Seal strength during storage at $-80^{\circ} \mathrm{C}$.

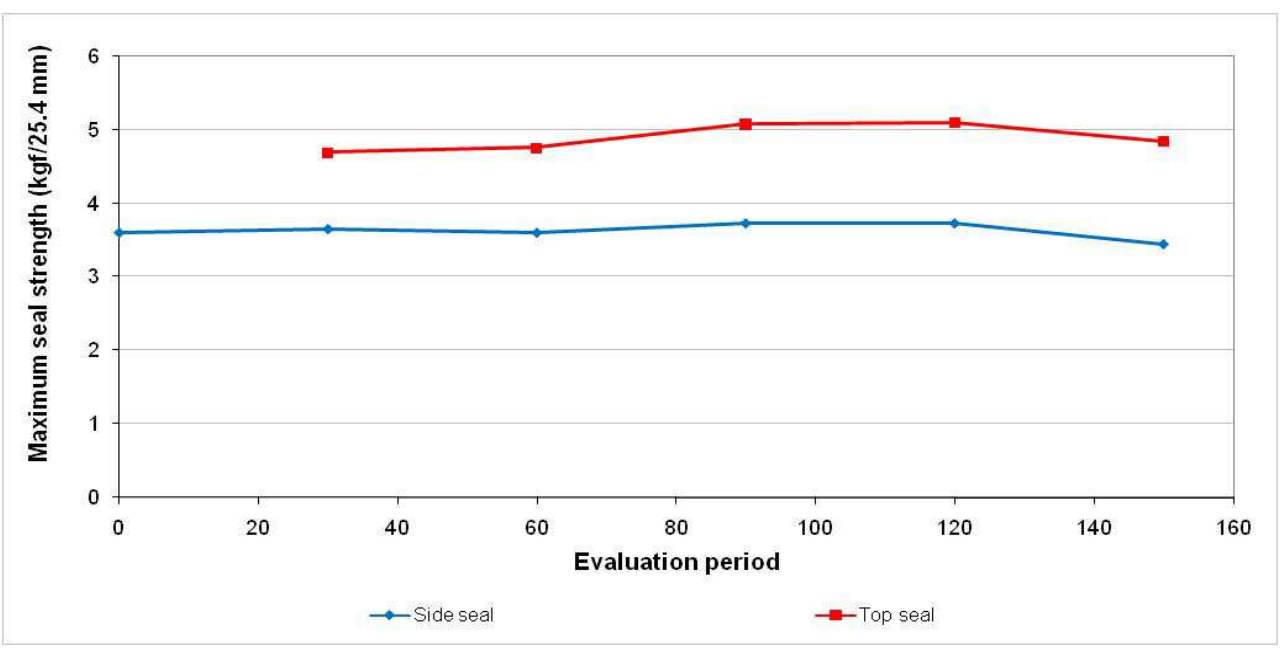

Fig. 4. Maximum seal strength during the period of storage at $-80^{\circ} \mathrm{C}$ ( days).

\section{D) Oxygen transmission rate}

The oxygen transmission rate at humid was determined by the coulometric method, according to the procedure described in ASTM F 1927 - Standard test method for determination of oxygen gas transmission rate, permeability and permeance at controlled relative humidity through barrier materials using a coulometric detector, on MOCON OXTRAN device, model $2 / 20$, operating with pure oxygen as permanent gas. The tests were carried out at $23^{\circ} \mathrm{C}$ to $75 \% \mathrm{RH}$, with the samples packaged for 88 to 112 hours in a temperature-controlled room at $25^{\circ} \mathrm{C}$ and $75 \% \mathrm{RH}$. The effective area of permeation of each sample was $50 \mathrm{~cm}^{2}$. The result obtained was corrected for $1 \mathrm{~atm}$ of partial pressure gradient of oxygen. 


\begin{tabular}{|c|c|c|c|c|c|c|}
\hline \multirow{2}{*}{$\begin{array}{c}\mathrm{O}_{2} \mathbf{T R} \\
\mathrm{mL}(\mathrm{STP}) \cdot \mathrm{m}^{-} \\
{ }^{2} \cdot \mathrm{day}^{-1} \text { at } \\
23^{\circ} \mathrm{C} / 75 \% \mathrm{RH}\end{array}$} & \multicolumn{6}{|c|}{ Evaluation periods (days) } \\
\hline & $\mathbf{0}$ & 30 & 60 & 90 & 120 & 150 \\
\hline Mean & $69.75^{a}$ & 75.95 a & 74.97 a & 82.57 a & 76.98 a & $113.67 \mathrm{~b}$ \\
\hline VI & $\begin{array}{c}68.63- \\
70.87\end{array}$ & $\begin{array}{l}71.77- \\
80.14\end{array}$ & $\begin{array}{l}74.48- \\
75.46\end{array}$ & $\begin{array}{c}79.34- \\
85.80\end{array}$ & $\begin{array}{c}73.83- \\
80.13\end{array}$ & $\begin{array}{l}105.05- \\
122.29\end{array}$ \\
\hline CV $(\%)$ & 2.3 & 7.8 & 0.9 & 5.5 & 5.8 & 10.7 \\
\hline
\end{tabular}

values relate to two determinations

VI - variation interval; CV - coefficient of variation

$\mathrm{a}, \mathrm{b}$ : for a seal type, mean values on the same line accompanied by the same superscript letter did not show any difference between them in the least significant difference (LSD) test, at a level of error of $5 \%$.

Table 5. Oxygen transmission rates $\left(\mathrm{O}_{2} \mathrm{TR}\right)$ during storage at $-80^{\circ} \mathrm{C}$.

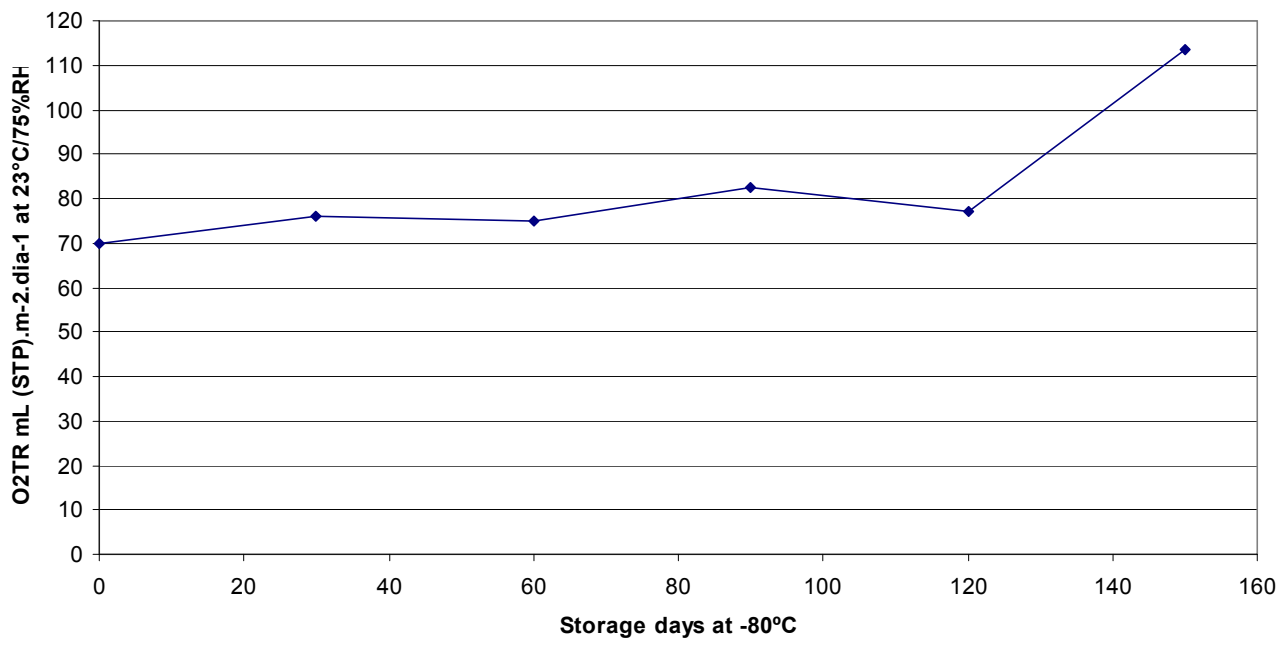

Fig. 5. Oxygen transmission rates $\left(\mathrm{O}_{2} \mathrm{TR}\right)$ during storage at $-80^{\circ} \mathrm{C}$.

The results of the oxygen permeability rates shown in Table 5 and Figure 5 indicate a mean increase of $10 \%$ in permeability after the process of sterilization, vacuum packaging of the bone, and storage at $-80^{\circ} \mathrm{C}$, which was observed after 30 days of storage. This tendency to increase, probably due to humidification of the PA, led to a small loss of barrier which was maintained throughout the storage period of 120 days. Meanwhile, in the analysis of samples from 30 days of storage at $-80^{\circ} \mathrm{C}$, a high oxygen transmission rate of was observed, which was not expected, and as we did not have any more stored samples, it was not possible to re-evaluate this result. This higher O2TR may be the result of some variation in thickness of the PA in the samples evaluated in this period. In any case, the level of oxygen transmission rate of the film did not lead to loss of vacuum in the samples stored in the Tissue Bank for 150 days at $-80^{\circ} \mathrm{C}$. 


\section{E) Overall Migration}

The evaluations of overall migration were performed according to Resolution 51 of 26 November 2010 published by Agência Nacional de Vigilância Sanitária do Ministério da Saúde (National Agency of Sanitary Surveillance of Health Ministry) in Diário Oficial da União (official journal of the Brazilian Government) on 30 November 2010. This Resolution internalizes Mercosul Technical Regulation GMC 32/10.

The methodology to quantify the overall migration was according to the method of the European Standard EN 1186-1: materials and articles in contact with foodstuffs. Plastics. Part 1: guide to the selection of conditions and test methods for overall migration, EN 11863: Materials and articles in contact with foodstuffs. Plastics. Test methods for overall migration into aqueous food simulants by total immersion and EN 1186-14: materials and articles in contact with foodstuffs. Plastics. Part 1: Part 14: test methods for "substitute tests" for overall migration from plastics intended to come into contact with fatty foodstuffs using test media isooctane and $95 \%$ ethanol and consists of the sample contact with extraction solutions in certain periods and temperatures that simulate their actual condition of use. The residues of overall migration were determined by the weight difference after the contact and evaporation of the solutions through an analytical scale with $0.01 \mathrm{mg}$ of accuracy. The sample was evaluated under the contact conditions shown in Table 6.

\begin{tabular}{cc}
\hline Model Solution & Contact condition \\
\hline Ultra purified water & $40^{\circ} \mathrm{C} / 10$ days \\
\hline $\begin{array}{c}\text { Acetic acid solution in Ultra purified } \\
\text { water at 3\% (w/v) }\end{array}$ & $40^{\circ} \mathrm{C} / 10$ days \\
\hline Isooctane & $40^{\circ} \mathrm{C} / 10$ days \\
\hline
\end{tabular}

Table 6. Conditions of time and temperature used in the overall migration.

The results of the overall migration tests performed on the transparent coextruded plastic film, obtained using the model solutions and the specific contact conditions are shown in Table 7.

\begin{tabular}{cccccc}
\hline $\begin{array}{c}\text { Model } \\
\text { Solution/Contact } \\
\text { Condition }\end{array}$ & $\begin{array}{c}\text { Maximum } \\
\text { limit of } \\
\text { overall } \\
\text { migration }\end{array}$ & Sample & Mean & $\begin{array}{c}\text { Standard } \\
\text { Deviation }\end{array}$ & $\begin{array}{c}\text { Variation } \\
\text { interval }\end{array}$ \\
\hline $\begin{array}{c}\text { Ultra purified } \\
\text { water/ }\end{array}$ & 8.0 & Before EtO & $\leq 0.72$ & 0.21 & $\leq 0.50^{(2)}-1.00$ \\
\cline { 3 - 6 } & After EtO & $\leq 0.51$ & 0.02 & $\leq 0.50^{(2)}-0.55$ \\
\hline $\begin{array}{c}3 \% \mathrm{C} / 10 \text { days } \\
\text { solution }(\mathrm{w} / \mathrm{v}) / \\
40^{\circ} \mathrm{C} / 10 \text { days }\end{array}$ & 8.0 & Before EtO & $\leq 0.54$ & 0.09 & $\leq 0.50^{(2)}-0.67$ \\
\cline { 3 - 6 } & & After EtO & 0.92 & 0.19 & $0.72-1.12$ \\
\hline $\begin{array}{c}\text { Isooctane/ } \\
20^{\circ} \mathrm{C} / 48 \text { hours }\end{array}$ & 8.0 & Before EtO & $\leq 1.21$ & 0.64 & $\leq 0.50^{(2)}-1.85$ \\
\cline { 3 - 6 } & & After EtO & $\leq 1.50$ & 0.72 & $\leq 0.50^{(2)}-2.05$ \\
\hline
\end{tabular}

(1) Result of four determinations.

(2) Limit of quantification of the method in the analytical conditions used.

(3) Not applicable.

Table 7. Residues of overall migration obtained for the transparent coextruded plastic film, before and after the application of $\mathrm{EtO}$, in $\mathrm{mg} / \mathrm{dm}^{2}(1)$. 
The maximum limit of overall migration provided by Resolution $\mathrm{n}^{\circ} 105 / 99$ is of $8 \mathrm{mg}$ of residue per $\mathrm{dm}^{2}$ of contact plastic material, with an analytical tolerance of $10 \%$. Therefore $8.8 \mathrm{mg} / \mathrm{dm}^{2}$ is the maximum tolerable value.

The overall migration values found in the samples analyzed, in the analytical conditions used, were below the established limit. There was no statistical significance with sterilization with ethylene oxide (EtO).

\section{E 1.) Physicochemical tests - According to USP 33}

The physicochemical tests were conducted based in the methodology describe in the Chapter <661> Containers - Plastics - Physicochemical Tests of the United States Pharmacopeia (USP 33).

In accordance to the United States Pharmacopeia, physicochemical tests are designed to determine physical and chemical properties of plastic materials. The extracts methodology consists of the sample contact with a extraction solution (deionized water) at $70^{\circ} \mathrm{C}$ during 24 hours, maintaining the ratio area / volume of $120 \mathrm{~cm}^{2}$ total surface area of plastic material for each $20 \mathrm{~mL}$ of extraction solution.

The analyzed sample was received in the form of the film cut into strips with dimensions of $5.0 \mathrm{~cm}$ long, $0.3 \mathrm{~cm}$ wide and thickness less than $0.1 \mathrm{~cm}$. In this case, the thickness of the material to determine the total area was not considered and was maintained the ratio of 120 $\mathrm{cm}^{2}$ for each $20 \mathrm{~mL}$ of extraction solution. Water was used as extraction solution.

After the contact, the extraction solution and blank reagent were analyzed by the following tests:

Buffering Capacity: Titrate $20 \mathrm{~mL}$ of the extraction solution potentiometrically to a $\mathrm{pH}$ of 7.0, using $0.01 \mathrm{~N}$ sodium hydroxide. Treat a $20.0 \mathrm{~mL}$ portion of the blank reagent similarly. The difference between the two volumes can not be greater than $10.0 \mathrm{~mL}$.

Nonvolatile Residue: $50 \mathrm{~mL}$ of the extraction solution were evaporated on a hot plate, after the residue was dried at $105^{\circ} \mathrm{C}$ for 1 hour on a oven and finally the nonvolatile residue was weighted through an analytical balance with $0.01 \mathrm{mg}$ of accuracy. Treat a $50.0 \mathrm{~mL}$ portion of the blank reagent similarly. The difference between the two volumes can not be greater than $15.0 \mathrm{mg}$.

Residue on Ignition: in the residues obtained in nonvolatile residues test, add sulfuric acid and burn on the muffle furnace until constant weight. Treat the blank reagent similarly. The difference between the two volumes should not be greater than $5.0 \mathrm{mg}$. It is not necessary to perform this test when the nonvolatile residue test result does not exceed $5.0 \mathrm{mg}$.

Heavy Metal, as lead: an aliquot of extraction solution has been transferred to a volumetric flask and acidified with nitric acid and the volume was completed with the extraction solution. After treating the sample, the lead content was quantified by atomic emission spectrometry induced by plasma, with an optical detector, in a Perkin Elmer equipment, model OPTIMA 2000DV, using appropriate calibration curves for the analyses. This test was conducted in replacement to the heavy metal test stablished by American Pharmacopeia, whose result is expressed as lead (and is based on the colour comparison among the test solution and a solution of lead with concentration of $1.0 \mathrm{mg} / \mathrm{kg}$ ). 


\begin{tabular}{|c|c|c|c|c|c|}
\hline $\begin{array}{c}\text { Physicochemical } \\
\text { Assay }\end{array}$ & $\begin{array}{c}\text { Limit based on } \\
\text { USP }\end{array}$ & Sample & Mean & $\begin{array}{l}\text { Standard } \\
\text { deviation }\end{array}$ & $\begin{array}{l}\text { Variation } \\
\text { interval }\end{array}$ \\
\hline \multirow{2}{*}{$\begin{array}{l}\text { Buffering capacity } \\
\qquad(\mathrm{mL})\end{array}$} & \multirow{2}{*}{$10.0 \mathrm{~mL}$} & Before EtO & $\leq 0.5^{(2)}$ & (3) & (3) \\
\hline & & After EtO & $\leq 0.5^{(2)}$ & (3) & (3) \\
\hline \multirow{2}{*}{$\begin{array}{l}\text { Non-volatile residue: } \\
(\mathrm{mg})\end{array}$} & \multirow{2}{*}{$15 \mathrm{mg}$} & Before EtO & $\leq 1.0^{(2)}$ & (3) & (3) \\
\hline & & After EtO & $\leq 1.0(2)$ & (3) & (3) \\
\hline \multirow{2}{*}{$\begin{array}{c}\text { Heavy Metals (as } \\
\text { lead) } \\
(\mathrm{mg} / \mathrm{kg}(\mathrm{ppm}))\end{array}$} & \multirow{2}{*}{$\begin{array}{c}1 \mathrm{mg} / \mathrm{kg} \\
(\mathrm{ppm})\end{array}$} & Before EtO & $\leq 0.05(2)$ & (3) & (3) \\
\hline & & After EtO & $\leq 0.05^{(2)}$ & (3) & (3) \\
\hline
\end{tabular}

(1) Results of three determinations.

(2) Corresponds to the limit of quantification of the method in the analytical conditions used.

(3) Values no applicable

Table 8. Physicochemical assays of the analyzed samples(1).

\section{E 2.) Assays According to the European Pharmacopoeia}

The tests acidity or alkalinity, sulfated ash, absorbance, extractable aluminum, chromium, titanium, vanadium, zinc, zirconium and extractables from heavy metals, expressed as lead were conducted based in the methodology described in the European Pharmacopoeia, Chapters "3.1.3 Polyolefines", "3.1.4 Polyethylene without Additives for Containers for Parenteral Preparations and for Ophthalmic Preparations" and "3.1.5 Polyethylene with Additives for Containers for Parenteral Preparations and for Ophthalmic Preparations".

\section{Extractables of aluminium, chromium, titanium, vanadium, zinc and zirconium}

The methodology for quantification of extractables aluminum, chromium, titanium, vanadium, zinc and zirconium involved contact of 100 grams of sample with a solution of $0.1 \mathrm{M}$ hydrochloric acid for one hour at the reflux temperature. After treating the sample, the metals contents were quantified by atomic emission spectrometry induced by plasma, with an optical detector, in a Perkin Elmer equipment, model OPTIMA 2000DV, using appropriate calibration curves for the analyses.

\section{Extractables of Heavy Metals, expressed as lead}

The same procedure described for quantification of extractable aluminum, chromium, titanium, vanadium, zinc and zirconium was used. The method for quantification of extractable lead was used instead of the colorimetric method of determination of heavy metals established by the European Pharmacopoeia, which is based on color comparison between the extracting solution and a solution of lead at a concentration of $2.5 \mathrm{mg} / \mathrm{kg}$.

\section{Alkalinity or Acidity, and Absorbance}

The method for quantification of alkalinity or acidity and absorbance involved contact of 12.5 grams of sample with $250 \mathrm{~mL}$ of deionized water for five hours at the reflux temperature.

After the extraction time, both the extracting solution in contact with the samples and a blank solution (reference) were assessed as to the following tests: 
Alkalinity and Acidity: measurement of $\mathrm{pH}$ in a Micronal pHmeter, model B 474 and titration of $100 \mathrm{~mL}$ of extracting solution with sodium hydroxide $0.01 \mathrm{M}$ or hydrochloric acid 0.01M up to $\mathrm{pH} 7.0$.

Absorbance: absorbance of the extracting solution was measured in the $220 \mathrm{~nm}$ to $340 \mathrm{~nm}$ wavelength range, using a quartz cuvette with $10 \mathrm{~mm}$ pathlenght in a UV / VIS spectrophotometer, using an Analytik Jena instrument, model Specord 210.

\section{Sulphated Ash}

Sulfated ash were assessed per requirements in European Pharmacopoeia 6.0, Chapter 2.4.14 - Sulfated Ash. The method for quantification of sulfated ash consisted in weighing $5.00 \mathrm{~g} \pm$ $0.01 \mathrm{~g}$ of sample on an analytical scale with $10^{-5} \mathrm{~g}$ resolution and incineration at a temperature of $600{ }^{\circ} \mathrm{C} \pm 20^{\circ} \mathrm{C}$ using a Milestone microwave heating furnace, model Pyro. After incinerating the sample, the ash were determined gravimetrically, using an analytical scale with $10^{-5} \mathrm{~g}$ resolution. There was not need to use sulfuric acid.

\section{Extractable aluminum, chromium, titanium, vanadium, zinc and zirconium}

The results of the extractable aluminum, chromium, titanium, vanadium, zinc and zirconium tests for the analyzed sample are shown in Table 9.

\begin{tabular}{|c|c|c|c|c|c|}
\hline Extractables & $\begin{array}{c}\text { Limit based on } \\
\text { European } \\
\text { Pharmacopeia } 6.0\end{array}$ & Sample & Mean & $\begin{array}{l}\text { Standard } \\
\text { Deviation }\end{array}$ & $\begin{array}{c}\text { Variation } \\
\text { interval }\end{array}$ \\
\hline \multirow{2}{*}{$\mathrm{Al}$} & \multirow{2}{*}{1.0} & Before $\mathrm{EtO}$ & 0.71 & 0.08 & $0.62-0.78$ \\
\hline & & After EtO & 0.74 & 0.06 & $0.70-0.81$ \\
\hline \multirow{2}{*}{$\mathrm{Cr}$} & \multirow{2}{*}{0.05} & Before $\mathrm{EtO}$ & 0.03 & 0.00 & $0.02-0.03$ \\
\hline & & After EtO & 0.33 & 0.05 & $0.27-0.37$ \\
\hline \multirow{2}{*}{$\mathrm{Ti}$} & \multirow{2}{*}{1.0} & Before EtO & $\leq 0.10^{(2)}$ & (3) & (3) \\
\hline & & After EtO & $\leq 0.10^{(2)}$ & (3) & (3) \\
\hline \multirow{2}{*}{$\mathrm{V}$} & \multirow{2}{*}{0.10} & Before $\mathrm{EtO}$ & $\leq 0.10^{(2)}$ & (3) & (3) \\
\hline & & After EtO & $\leq 0.10^{(2)}$ & (3) & (3) \\
\hline \multirow{2}{*}{$\mathrm{Zn}$} & \multirow{2}{*}{1.0} & Before EtO & 0.05 & 0.00 & $0.05-0.06$ \\
\hline & & After EtO & 0.05 & 0.01 & $0.05-0.06$ \\
\hline \multirow{2}{*}{$\mathrm{Zr}$} & \multirow{2}{*}{0.10} & Before $\mathrm{EtO}$ & $\leq 0.05^{(2)}$ & (3) & (3) \\
\hline & & After EtO & $\leq 0.05(2)$ & (3) & (3) \\
\hline
\end{tabular}

(1) Result of four determinations.

(2) Corresponds to the limit of quantification of the equipment in the analytical conditions used.

(3) Not applicable.

Table 9. Extractables of the metals aluminum $(\mathrm{Al})$, chromium $(\mathrm{Cr})$, titanium $(\mathrm{Ti})$, vanadium (V), zinc $(\mathrm{Zn})$ and zirconium $(\mathrm{Zr})$, in $\mathrm{mg} / \mathrm{kg}^{(1)}$.

\section{Extractable Heavy Metal, Expressed as Lead}

The results of the extractable heavy metals, expressed as lead, acidity, absorbance and sulphated ash tests, for the analyzed sample are shown in Table 10. 


\begin{tabular}{|c|c|c|c|c|c|}
\hline $\begin{array}{c}\text { Physicochemical } \\
\text { Assay }\end{array}$ & $\begin{array}{c}\text { Limit based on } \\
\text { European } \\
\text { Pharmacopeia } 6.0\end{array}$ & Sample & Mean & $\begin{array}{l}\text { Standard } \\
\text { Deviation }\end{array}$ & $\begin{array}{c}\text { Variation } \\
\text { interval }\end{array}$ \\
\hline \multirow{2}{*}{$\begin{array}{c}\text { Extractables of Heavy } \\
\text { Metals, expressed as } \\
\text { lead } \\
(\mathrm{ppm}) \\
\end{array}$} & \multirow{2}{*}{$2.5 \mathrm{mg} / \mathrm{kg}(\mathrm{ppm})$} & Before EtO & $\leq 0.1^{(2)}$ & (3) & (3) \\
\hline & & After EtO & $\leq 0.1^{(2)}$ & (3) & (3) \\
\hline \multirow{2}{*}{$\begin{array}{c}\text { Acidity } \\
(\mathrm{mL} \text { of } \mathrm{NaOH} 0.01 \mathrm{M})\end{array}$} & \multirow{2}{*}{$\begin{array}{l}1.5 \mathrm{~mL} \text { de sodium } \\
\text { hydroxide } 0.01 \mathrm{M}\end{array}$} & Before EtO & $\leq 0.5^{(2)}$ & (3) & (3) \\
\hline & & After EtO & $\leq 0.5^{(2)}$ & (3) & (3) \\
\hline \multirow{2}{*}{$\begin{array}{l}\text { Absorbance } \\
\text { (UA) }\end{array}$} & \multirow{2}{*}{$0.2 \mathrm{UA}$} & Before EtO & 0.23 & 0.01 & $0.22-0.23$ \\
\hline & & After EtO & 0.24 & 0.04 & $0.22-0.26$ \\
\hline \multirow{2}{*}{$\begin{array}{l}\text { Sulphated Ash } \\
(\%)\end{array}$} & \multirow{2}{*}{$0.02 \%$ and $1.00 \%(4)$} & Before EtO & 0.29 & 0.01 & $0.28-0.30$ \\
\hline & & After EtO & 0.25 & 0.12 & $0.11-0.33$ \\
\hline
\end{tabular}

UA- Unit of Absorbance.

(1) Results of three determinations.

(2) Corresponds to the limit of quantification of the method in the analytical conditions used.

(3) Values no applicable

(4) Varies according to the presence of additives

Table 10. Results for heavy metals, expressed as lead, acidity, absorbance and ash of the samples analyzed (1).

The lead values, volume of $0.1 \mathrm{M}$ sodium hydroxide used, and sulphated ash values found in the samples analyzed were below the maximum limits established in the European Pharmacopeia 6.0. In relation to absorbance, the values obtained in the two samples analyzed, before and after the application of sterilization with ethylene oxide (EtO), were slightly higher than the maximum limits established.

A038-2/11 - Packaging for human tissue - Final Report 17/20 This means that some substance of the coextruded film may have migrated to the extraction solution in contact with the sample (deionized water), a fact that requires further investigation.

It should be emphasized that the methodology of the American and European Pharmacopeias apply to single-layer packaging, and that substances from internal layers of the film analyzed may have been extracted, slightly increasing the absorbance of the extraction solution.

\section{E 3.) Specific migration}

The extruded film before and after sterilization with ethylene oxide was evaluated in relation to specific migration of 1-octene and $\varepsilon$-caprolactam. The evaluations of specific migrations of 1-octene, $\varepsilon$-caprolactam and hexamethylenediamine were carried out according to the Brazilian legislation.

\section{E 3.1) Specific migration of 1-octene}

The quantification of specific migration of 1-octene was evaluated based on Standard CEN/ TS 13130-26: materials and articles in contact with foodstuffs - Plastics substances subject to limitation - Part 26: 
Determination of 1-octene and tetrahydrofuran in food simulants, and consists of contact of the sample with solutions of extraction with times and temperatures that simulate its real condition of use.

The internal sides of the samples were placed in contact with the simulants, obeying an area:volume ratio of $600 \mathrm{~cm} 2$ to $1000 \mathrm{~mL}$. The same was evaluated in the contact conditions shown in Table 11.

\begin{tabular}{cccccc}
\hline $\begin{array}{c}\text { Simulants/Contact } \\
\text { Condition }\end{array}$ & $\begin{array}{c}\text { Maximum limit of } \\
\text { specific migration } \\
\text { of 1-octene }\end{array}$ & Sample & Mean (1) & $\begin{array}{c}\text { Standar } \\
\mathbf{d} \\
\text { Deviatio } \\
\mathbf{n}\end{array}$ & $\begin{array}{c}\text { Variation } \\
\text { Interval }\end{array}$ \\
\hline $\begin{array}{c}\text { Ultra purified water/ } \\
40^{\circ} \mathrm{C} / 10 \text { days }\end{array}$ & 15 & Before EtO & $\leq 2.8^{(2)}$ & $(3)$ & $(3)$ \\
\hline $\begin{array}{c}3 \% \text { Acetic acid solution } \\
\text { in ultra purified water } \\
\text { (w/v)/ }\end{array}$ & 15 & After EtO & $\leq 2.8^{(2)}$ & $(3)$ & $(3)$ \\
\cline { 2 - 6 } $40^{\circ} \mathrm{C} / 10$ days & Before EtO & $\leq 1.6^{(2)}$ & $(3)$ & $(3)$ \\
\hline $\begin{array}{c}\text { Olive oil/ } \\
40^{\circ} \mathrm{C} / 10 \text { days }\end{array}$ & 15 & After EtO & $\leq 1.6^{(2)}$ & $(3)$ & $(3)$ \\
\hline
\end{tabular}

(1) Result of three determinations.

(2) Quantification Limit of the method under the analytical conditions.

(3) Not applicable.

Table 11. Specific migration of 1-octene obtained for transparent coextruded plastic film, before and after the application of $\mathrm{EtO}$, in $\mathrm{mg} / \mathrm{dm}^{2}$.

The specific limit of monomer migration of 1-octene established in Resolution 105/99 of the National

Health Surveillance Agency - ANVISA of 19 May 1999 is $15 \mathrm{mg} / \mathrm{kg}$ of simulant. The values for specific migration of 1-octene found in the samples analyzed, in the analytical conditions used, were below the established limit. Sterilization with ethylene oxide (EtO) did not affect the monomer migration potential of 1-octene.

\section{E 3.2) Specific migration of $\varepsilon$-caprolactam}

The quantification of specific $\varepsilon$-caprolactam was evaluated based on Standard CEN/ TS 13130-16: materials and articles in contact with foodstuffs - Plastics substances subject to limitation - Part 16: Determination of caprolactam and caprolactam salt in food simulants.

The internal surfaces of the samples were placed in contact with the simulants, obeying an area:volume ratio of $600 \mathrm{~cm} 2 / 1000 \mathrm{~mL}$. The samples were evaluated under the contact conditions shown in Table 12.

The specific limit of monomer migration of $\varepsilon$-caprolactam established in Resolution 105/99 of the National Health Surveillance Agency - ANVISA of 19 May 1999 is $15 \mathrm{mg} / \mathrm{kg}$ of simulant. The values for specific migration of $\varepsilon$-caprolactam found in the samples analyzed, in the analytical conditions used, were below the established limit. Sterilization with ethylene oxide (EtO) did not affect the potential monomer migration of $\varepsilon$-caprolactam for the fatty simulant, but was significantly lower (probability of $95 \%$ confidence - Tukey Test) 
for the ultrapure water simulants and 3\% acetic acid solution $(\mathrm{m} / \mathrm{v})$ in ultrapure water after sterilization with ethylene oxide.

\begin{tabular}{cccccc}
\hline $\begin{array}{c}\text { Simulants/Contact } \\
\text { Condition }\end{array}$ & $\begin{array}{c}\text { Maximum limit of } \\
\text { specific migration of } \\
\text { e-caprolactam }\end{array}$ & Sample & Mean $(1)$ & $\begin{array}{c}\text { Standard } \\
\text { Deviation }\end{array}$ & $\begin{array}{c}\text { Variation } \\
\text { Interval }\end{array}$ \\
\hline $\begin{array}{c}\text { Ultra purified water/ } \\
40^{\circ} \mathrm{C} / 10 \text { days }\end{array}$ & 15 & Before EtO & 2.4 & 0.3 & $1.9-2.7$ \\
\cline { 2 - 6 } & 15 & After EtO & 1.7 & 0.2 & $1.3-1.9$ \\
\hline $\begin{array}{c}3 \% \text { Acetic acid solution } \\
\text { in ultra purified water } \\
(\mathrm{w} / \mathrm{v}) / \\
40^{\circ} \mathrm{C} / 10 \text { days }\end{array}$ & 15 & After EtO & 2.2 & 0.3 & $1.8-2.6$ \\
\hline $\begin{array}{c}\text { Olive oil/ } \\
40^{\circ} \mathrm{C} / 10 \text { days }\end{array}$ & Before EtO & 3.4 & 0.4 & $3.0-4.0$ \\
\cline { 2 - 6 } & After EtO & 3.2 & 0.2 & $2.9-3.5$ \\
\hline
\end{tabular}

(1) Result of three determinations.

Table 12. Specific migration of $\varepsilon$-caprolactam obtained for transparent coextruded plastic film, before and after the application of $\mathrm{EtO}$, in $\mathrm{mg} / \mathrm{dm}^{2}$.

\section{E 3.3) Specific migration of hexamethylenediamine}

The quantification of specific hexamethylenediamine migration was evaluated based on Standard CEN/ TS 13130-21: materials and articles in contact with foodstuffs - Plastics substances subject to limitation - Part 21: Determination of ethylenediamine and hexamethylenediamine in food simulants. The sample of hexamethylenediamine, adipic acid e caprolactam copolyamide in the form of a film, was placed in contact with the simulants, obeying an area:volume ratio of $600 \mathrm{~cm} 2$ to $1000 \mathrm{~mL}$. The sample was evaluated under the contact conditions shown in Table 13.

\begin{tabular}{|c|c|c|c|c|}
\hline Simulants/Contact Condition & $\begin{array}{c}\text { Maximum limit of specific } \\
\text { migration of } \\
\text { hexamethylenediamine }\end{array}$ & Mean (1) & $\begin{array}{l}\text { Standard } \\
\text { Deviation }\end{array}$ & $\begin{array}{c}\text { Variation } \\
\text { Interval }\end{array}$ \\
\hline $\begin{array}{l}\text { Ultra purified water } / \\
100^{\circ} \mathrm{C} / 30 \text { minutes }+40^{\circ} \mathrm{C} / 10 \\
\text { days }\end{array}$ & 2,4 & $\leq 1.2^{(2)}$ & (3) & (3) \\
\hline $\begin{array}{l}3 \% \text { Acetic acid solution in ultra } \\
\text { purified water }(\mathrm{w} / \mathrm{v}) / \\
100^{\circ} \mathrm{C} / 30 \text { minutes }+40^{\circ} \mathrm{C} / 10 \\
\text { days }\end{array}$ & 2,4 & $\leq 1.1^{(2)}$ & (3) & (3) \\
\hline $\begin{array}{c}\text { Olive oil/ } \\
100{ }^{\circ} \mathrm{C} / 30 \text { minutes }+40{ }^{\circ} \mathrm{C} / 10 \\
\text { days }\end{array}$ & 2,4 & $\leq 2.0^{(2)}$ & (3) & (3) \\
\hline
\end{tabular}

(1) Result of three determinations.

(2) Quantification Limit of the method under the analytical conditions.

(3) Not applicable.

Table 13. Specific migration of hexamethylenediamine obtained for a $42 \mu \mathrm{m}$ film copolyamide, in $\mathrm{mg} / \mathrm{kg}$. 
The specific limit of monomer migration of hexamethylenediamine established in Resolution 105/99 of the National Health Surveillance Agency - ANVISA of 19 May 1999 is $2.4 \mathrm{mg} / \mathrm{kg}$ of simulant. The values for specific migration of hexamethylenediamine found in the analysis of the $42 \mu \mathrm{m}$ film copolyamide, under the analytical conditions used, were below the established limit.

\subsection{Cytotoxicity assay}

Assay performed in accordance with Standard ISO 10993-5: Biological evaluation of medical devices - Part 5: Cytotoxicity Assays: in vitro methods in samples of coextruded plastic film.

\subsubsection{Cytotoxicity}

Definitions of cytotoxicity vary, depending on the nature of the study and whether cells are killed or simply have their metabolism altered. Cytotoxicity is the toxicological effect that a substance can cause in vitro, at cellular level (Freshney, 2000).

As defined in ISO 10993, "the numerous methods used and end-points measured in cytotoxicity determination can be grouped into categories of evaluation type, like assessments of cell damage by morphological means; measurements of cell damage; measurements of cell growth and measurements of specific aspects of cellular metabolism" [IOS, 2010]. The cells can be exposed to the samples or their extracts.

\subsubsection{The protocols}

\section{Cell culture}

Chinese hamster ovary cell line (CHO-k1) was standardized for cytotoxicity and genotoxicity tests. Cells were maintained in RPMI medium supplemented with antibiotics and antimycotics (100 units/mL penicillin, $100 \mu \mathrm{g} / \mathrm{mL}$ streptomycin and $0.025 \mu \mathrm{g} / \mathrm{mL}$ amphotericin), $2 \mathrm{mM}$ glutamine, and $10 \%$ calf serum, at $37 \circ \mathrm{C}$ in a humidified $5 \% \mathrm{CO}_{2}$ atmosphere until they reached confluence. For subculturing and for experiments, cells were harvested using $0.05 \%$ trypsin and $0.02 \%$ EDTA in phosphate-buffered saline, pH 7.4.

\section{Extract preparation}

Samples of packaging, before and after sterilization, were submitted to this assay. The samples were immersed separately in RPMI culture medium at a final concentration of 1 $\mathrm{cm}^{2} / \mathrm{mL}$ and left in an incubator at $37^{\circ} \mathrm{C}$ for 72 hours to fulfil the extraction condition. The first concentration was sterilized by filtration and the subsequent dilutions were performed in sterile RPMI medium at a ratio of 1:2.

\section{Cytotoxicity test}

A colorimetric method that uses the tetrazolium compound MTS was used to determine the number of viable cells in proliferation (Cory et al, 1991). 96-well microplates were prepared with $50 \mu \mathrm{L}$ of extract diluted from 100 to $6.25 \%$ in RPMI medium in quadruplicates. The positive control was a phenol solution $(0.5 \% \mathrm{v} / \mathrm{v})$ as $100 \%$ concentration and the negative control was a high density polyethylene (HDPE) extract. The $100 \%$ concentration was the 
non-extract well A suspension of $\mathrm{CHO}-\mathrm{k} 1$ (from second to fourth passages after thawing) with $6 \times 10^{4} \mathrm{cell} / \mathrm{mL}$ was prepared and $50 \mu \mathrm{L} /$ well was pipetted into the microplates. The microplates were incubated for 72 hours at $37{ }^{\circ} \mathrm{C}$ in a humidified $5 \% \mathrm{CO}_{2}$ atmosphere. Blank and controls of the cells were also prepared. Cell viability was measured by adding $20 \mu \mathrm{L}$ of MTS/PMS (20:1) solution to the humidified 5\% $\mathrm{CO}_{2}$ incubator, followed by incubation for 2 hours at $37^{\circ} \mathrm{C}$. The microplates were read in a spectrophotometer reader at $490 \mathrm{~nm}$.

Cell viability was calculated by the equation:

$$
\mathrm{CV} \%=\frac{\text { OD sample }}{\text { ODnonextract }} \times 100
$$

Where: $\mathrm{CV} \%$ = cell viability, $\mathrm{OD}$ sample = optical density at $490 \mathrm{~nm}$ of the extract dilution, OD non extract $=$ optical density at $490 \mathrm{~nm}$ of the well without extract.

The results consider the following parameters:

a. Controls (positive and negative)

Positive control: $0.5 \%$ Phenol solution

Negative control: HDPE (high-density polyethylene) extract.

b. Observations: definitions of some terms.

- Positive control: material which, when tested according to Standard ISO 10993-5, promotes a cytotoxic response.

- Negative control: material which, when tested according to Standard ISO 10993-5, does not promote a cytotoxic response.

- $\mathrm{IC}_{50(\%)}$ : cytotoxicity index $50 \%$, concentration of extract that kills $50 \%$ of the viable cell population.

The results of the assay showed that the samples of packaging material, before and after sterilization by ethylene oxide (EtO), resulted in viability of over $90 \%$, and therefore do not become cytotoxic.

\subsection{Sterility assay and ethylene oxide residues}

The samples were classified according to their position ( 0 to $5 \mathrm{a} ; 0$ to $5 \mathrm{~b})$ during exposure to $\mathrm{EtO}$, for the penetration analysis. The outermost or surface position corresponds to the number 5 , and the innermost position to the number 0. (Figure 6)

Sterility tests were carried out through the analyses of two biological indicators (bi $3 \mathrm{M}$ ATTEST _TM Bacillus atrophaeus and Terragene - Bionova BT40 - Bacillus atrophaeus). Incubation time was $48 \mathrm{~h}$ at a temperature of $35^{\circ} \mathrm{C} \pm 1.5$.

Samples of packaging were also submitted to direct incubation for 7 days with TSB liquid culture at a temperature of $35^{\circ} \mathrm{C} \pm 1.5$. The methodology used is in accordance with the Brazilian Pharmacopoeia. The analyses of the three sterility tests (biological indicator Bionova BT40, 3Mattest and direct incubation) confirm the sterility of the packaging material after being submitted to ethylene oxide gas. 


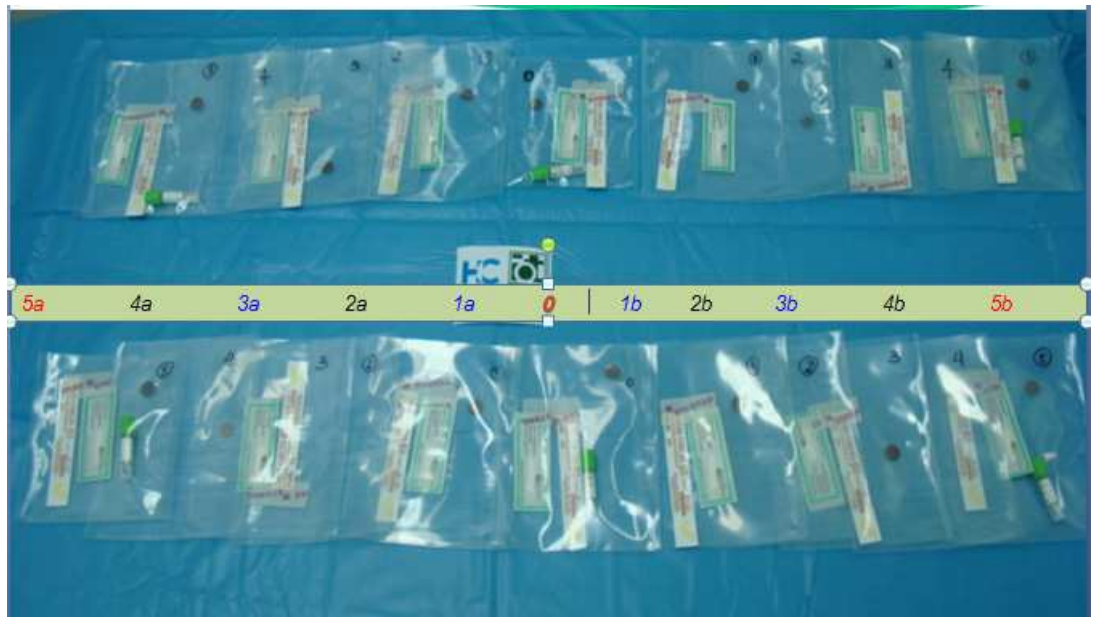

Fig. 6. Samples of packaging positioned from 0 to 5 for EtO penetration analysis.
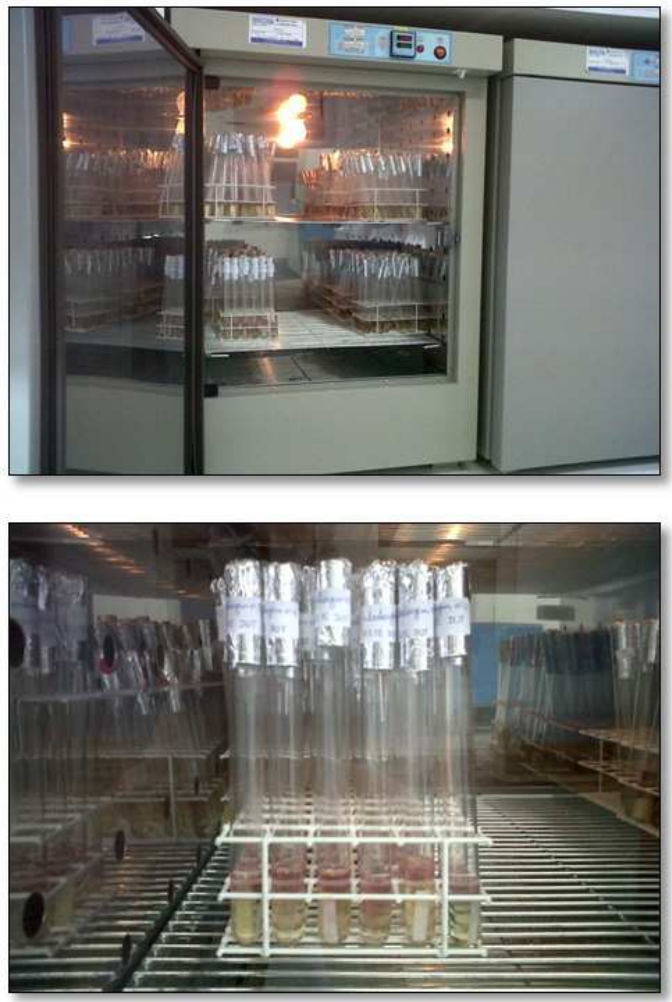

Fig. 7 and 8 . Performance of the sterility test by direct incubation in samples submitted to ethylene oxide. 
The analysis of ethylene oxide residues was performed by the Gas Chromatography test, determining the levels of Ethylene chlorohydrin and Ethylene glycol. The data are shown in Figure 9 and show that the levels are within the limits accepted by our legislation.

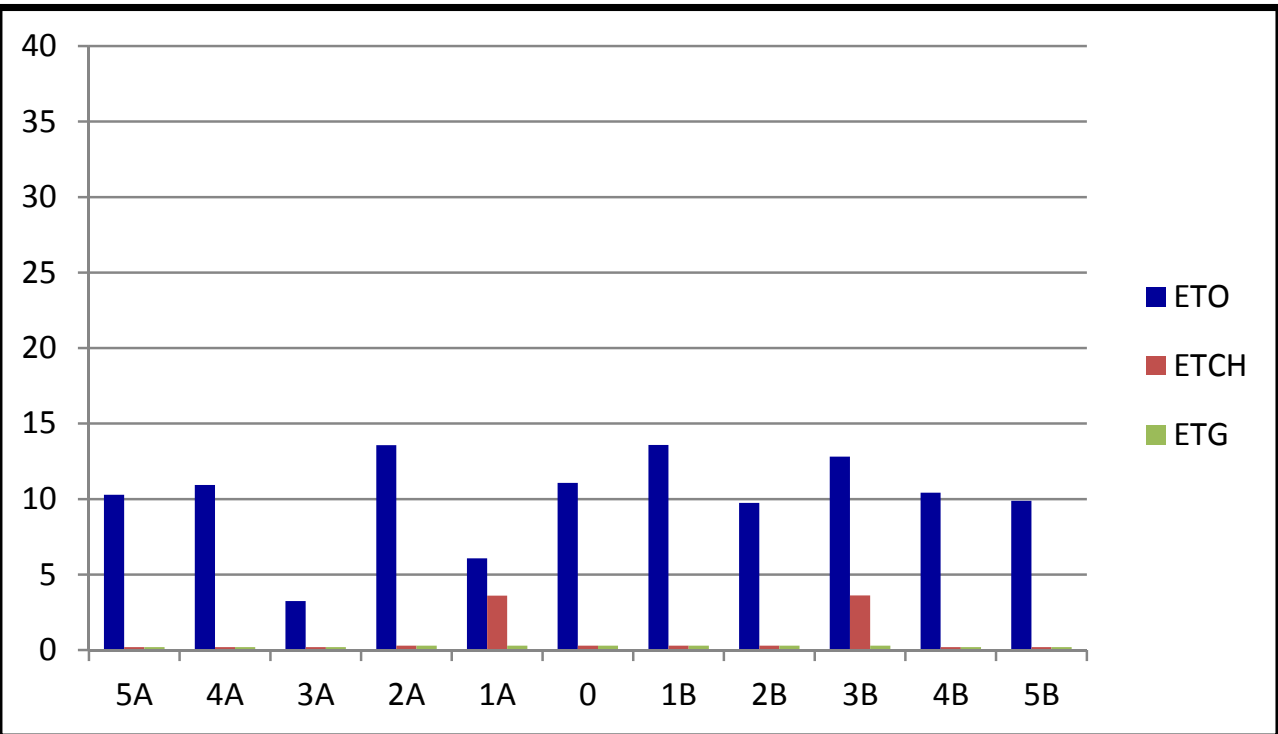

Note. Maximum limits according to the Brazilian legislation. [ ETO up to 25/ ETCH up to 25/ETG up to 250]

Fig. 9. Residues (ETO, ETCH, ETG) found in the samples submitted to sterilization.

\section{Final considerations}

Analyses of the packaging used in this study demonstrated that it is a good option for cryopreservation of tissues at a temperature of $-80^{\circ} \mathrm{C}$.

Our experience with assays to validate coextruded polyethylene and polyamide plastic film shows that the mechanical properties of this material are not altered by cryopreservation and sterilization. Penetration resistance of the thermal seal remained unaltered after all the processes carried out in a tissue bank, such as sterilization and cryopreservation.

We found a loss of barrier due to increased oxygen permeability of around $10 \%$ after sterilization and cryopreservation, which can be explained by the humidification of the polyamide. However, this slight alteration in oxygen permeability does not compromise the inner vacuum of the packaging, and does not place at risk the tissue packaged in it.

In relation to total migration, we did not observe any alterations in the assays, i.e. once again, sterilization and cryopreservation did not lead to monomer migration at levels above 
those required by our legislation. This is also valid for specific migrations of 1-octene, $\varepsilon-$ caprolactam and hexamethylenediamine.

The application of ethylene oxide is safe for sterilization of this type of packaging, as it results in good penetrability and safe levels of Eto, Etch and Etg residues at the end of the procedure.

In the cytotoxicity test, we observed levels of cell viability of over $90 \%$, therefore they do not become cytotoxic.

Thus, analyses of coextruded plastic polyethylene and polyamide film used in this study proved to be a good option for cryopreservation of tissues at temperatures of $-80^{\circ} \mathrm{C}$, even for prolonged periods of 150 days.

\section{References}

American Association of Tissue Banks. Standards for Tissue Banking. 11th ed. Mclean : American Association of Tissue Banks; 2007.

ASTM INTERNATIONAL. ASTM F1927-07: standard test method for determination of oxygen gas transmission rate, permeability and permeance at controlled humidity through barrier materials using a coulometric detector. Philadelphia, 2007. 6 p.

ASTM INTERNATIONAL. F 1306-90 (2008) e1: standard test method for slow rate penetration resistance of flexible barrier films and laminates. Philadelphia, 1990. $5 \mathrm{p}$.

ASTM INTERNATIONAL. F 88/F 88M-09: standard test method for seal strength of flexible barrier materials. Philadelphia, 2007. 11p.

BRASIL, Leis etc. Decreto n.2268 de 30 de junho de 1997. Dispõe sobre a remoção de órgãos, tecidos e partes do corpo humano para fins de transplantes e tratamento. Diário Oficial da União, Brasília (DF). 199730 jun; seção 1:1.

BRASIL, Leis etc. Lei n.9434 de 5 de fevereiro de 1997. Dispõe sobre a remoção de órgãos, tecidos e partes do corpo humano para fins de transplantes e tratamento. Diário Oficial da União, Brasília (DF). 19975 fev; seção 1:25.

BRASIL, Leis etc. Portaria n.1686 de 20 de setembro de 2002. Dispõe sobre a regulamentação para funcionamento de banco de tecidos músculo esqueléticos. Diário Oficial da União, Brasília (DF). 200224 jul; seção 1:1.

BRASIL, Leis etc. PORTARIA No 2.600, DE 21 DE OUTUBRO DE 2009. Aprova o Regulamento Técnico do Sistema Nacional de Transplantes. Diário Oficial da União, Brasília (DF). 2009 21out.

BRASIL, Leis etc. Resolução n. 220 de 27 de dezembro de 2006. Dispõe sobre o Regulamento Técnico para o Funcionamento de Bancos de Tecidos Musculoesqueléticos e de Bancos de Pele de origem humana. Diário Oficial da União, Brasília (DF). 200629 dez.

BRASIL. Agência Nacional de Vigilância Sanitária.ANVISA. Resolução no 105 de 19 de maio de 1999. Aprova o regulamento técnico sobre disposições gerais para embalagens e quipamentos plásticos em contato com alimentos. Diário Oficial 
[da] República Federativa do Brasil, Brasília, DF, 20 maio, 1999a. N. 95, Seção 1,p.21-34.

BRASIL. Ministério da Saúde - Agência Nacional de Vigilância Sanitária. Resolução - RDC $\mathrm{n}^{\circ} 51$ de 26 de novembro de 2010. Dispõe sobre migração em materiais, embalagens equipamentos plásticos destinados a entrar em contato com alimentos. Diário Oficial da República Federativa do Brasil, Brasília, DF, 22 dez. 2010. Seção 1, n. 244, p. 75-79.

Cory,AH; Owen,TC; Barltrop,JA; Cory, JG. (1991). Use of an aqueous soluble tetrazolium/formazan assay for cell growth assays in culture. Cancer Comm., 3, 207-212.

European Association of Tissue Banks. Common Standards for Tissues and Cells Banking: Berlin: European Association of Tissue Banks; 2004.

EUROPEAN COMMITEE FOR STANDARDIZATION - CEN/TS 13130-16: materials and articles in contact with foodstuffs - Plastics substances subject to limitation - Part 16: Determination of caprolactam and caprolactam salt in food simulants. February 2005. 15p.

EUROPEAN COMMITEE FOR STANDARDIZATION - CEN/TS 13130-21: materials and articles in contact with foodstuffs - Plastics substances subject to limitation - Part 21: Determination of of ethylenediamine and hexamethylenediamine in food simulants. February 2005. 17p.

EUROPEAN COMMITEE FOR STANDARDIZATION - CEN/TS 13130-26: materials and articles in contact with foodstuffs - Plastics substances subject to limitation - Part 26: Determination of 1-octene and tetrahydrofuran in food simulants. February 2005. 25p.

EUROPEAN COMMITTEE FOR STANDARDIZATION. EN 1186-1: materials and articles in contact with foodstuffs - plastics. Part 1: guide to the selection of conditions and test methods for overall migration. Brussels, 2002. 49 p.

EUROPEAN COMMITTEE FOR STANDARDIZATION. EN 1186-14: materials and articles in contact with foodstuffs - plastics. Part 14: test methods for "substitute tests" for overall migration from plastics intended to come into contact with fatty foodstuffs using test media iso-octane and 95\% ethanol. Brussels, 2002. 20 p.

EUROPEAN COMMITTEE FOR STANDARDIZATION. EN 1186-3: materials and articles in contact with foodstuffs - plastics Part 3: test methods for overall migration into aqueous food simulants by total immersion. Brussels, 2002. $17 \mathrm{p}$.

EUROPEAN PHARMACOPOEIA. 6. ed. Strasbourg, France: European Department for the Quality of Medicines, 2008.

Freshney, RI (2000). Culture of animal cells: a manual of basic technique. 4.ed. New York: Wiley, 577p.

GRUPO MERCADO COMÚN. Mercosur//GMC/Res. no 32/10. Regulamento técnico Mercosur sobre migración en materiales, envases y equipamientos plásticos destinados a estar en contato con alimentos. Disponível em:

<http://www.puntofocal.gov.ar/doc/r_gmc_32-10.pdf>. Acesso em: 22 ago. 2011 
International Organization For Standardization. (2010), ISO 10993-5; Biological evaluation of medical devices - Part 5: Tests for cytotoxicity: in vitro methods. Switzerland

Rockville: The United States Pharmacopeial Convention, Inc., 2010.

THE UNITED STATES PHARMACOPEIAL CONVENTION. The United States Pharmacopeia. USP 33; NF 28. 


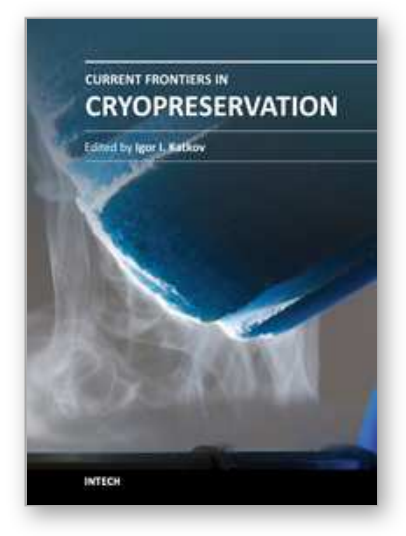

\author{
Current Frontiers in Cryopreservation \\ Edited by Prof. Igor Katkov
}

ISBN 978-953-51-0302-8

Hard cover, 462 pages

Publisher InTech

Published online 14, March, 2012

Published in print edition March, 2012

Almost a decade has passed since the last textbook on the science of cryobiology, Life in the Frozen State, was published. Recently, there have been some serious tectonic shifts in cryobiology which were perhaps not seen on the surface but will have a profound effect on both the future of cryobiology and the development of new cryopreservation methods. We feel that it is time to revise the previous paradigms and dogmas, discuss the conceptually new cryobiological ideas, and introduce the recently emerged practical protocols for cryopreservation. The present books, "Current Frontiers in Cryobiology" and "Current Frontiers in Cryopreservation" will serve the purpose. This is a global effort by scientists from 27 countries from all continents and we hope it will be interesting to a wide audience.

\title{
How to reference
}

In order to correctly reference this scholarly work, feel free to copy and paste the following:

Luiz Augusto Ubirajara Santos, Rosa Maria Vercelino Alves, Alberto T. Fábio Gomes Teixeira, Paulo Henrique Kiyataka, Marisa Padula, Mary Ângela Fávaro Perez, Monica Beatriz Mathor, Renata Miranda Parca, Arlete M.M . Giovani, Cesar Augusto Martins Pereira, Graziela Guidoni Maragni1, Thais Queiróz Santolin1 and Lucas da Silva Pereira (2012). Validation of Primary Packaging for Cryopreserved Musculoskeletal Tissues, Current Frontiers in Cryopreservation, Prof. Igor Katkov (Ed.), ISBN: 978-953-51-0302-8, InTech, Available from: http://www.intechopen.com/books/current-frontiers-in-cryopreservation/validation-of-primary-packaging-forconditioning-cryopreserved-musculoskeletal-tissues

\section{INTECH}

open science | open minds

\section{InTech Europe}

University Campus STeP Ri

Slavka Krautzeka 83/A

51000 Rijeka, Croatia

Phone: +385 (51) 770447

Fax: +385 (51) 686166

www.intechopen.com

\section{InTech China}

Unit 405, Office Block, Hotel Equatorial Shanghai

No.65, Yan An Road (West), Shanghai, 200040, China

中国上海市延安西路65号上海国际贵都大饭店办公楼 405 单元

Phone: +86-21-62489820

Fax: $+86-21-62489821$ 
(C) 2012 The Author(s). Licensee IntechOpen. This is an open access article distributed under the terms of the Creative Commons Attribution 3.0 License, which permits unrestricted use, distribution, and reproduction in any medium, provided the original work is properly cited. 